\title{
SYSTEMATIZING THE TEACHING OF ENGLISH VOWEL PHONEMES
}

\author{
Charles Michalski
}

\author{
Instituce of Inter-American Affairs, Education Division \\ and \\ University of Michigan
}

(Mr. Michalski, of the English Language Institute of the University of Michigan, has just returned from Peru, where he served as the English Teaching Specialist for the Education Division of the Institute of Inter-American Affairs. For the last four years he has been training and working with teachers of English in Peru, Chile, puerto Rico and Bolivia.)

One of the principal weaknesses in the teaching of English as a foreign language in many Latin American countries is the haphazard way in which pronunciation is usually taught. In most cases pronunciation difficulties are either completely ignored or treated incidentally, and no systematic presentation of the sounds of English, its common intonation patterns and characteristic rhythm is attempted. Even native speakers of English who teach their language to foreigners, although aware of the great difficulty of developing acceptable pronunciation habits in their students, are not aware of the attainable goals of this phase of English teaching and are unable to give a systematic presentation of the sound system of English.

To help teachers deal with one part of this problem, that is, the presentation of the English vowel phonemes, a sample set of drill cards for use at any level and with any textbook was prepared and demonstrated to Peruvian teachers of English attending teacher-training courses this year at the University of Arequipa and at the Cultural Institute in Lima, Peru. Some teachers promptly made duplicate sets of these visual aids by hand, while approximately one hundred of them ordered sets made by a professional printer.

Less than two months of using these cards in their classrooms convinced the teachers of their useability and usefulness. By concentrating on one pronunciation goal at a 
time, they began to see the value of a systematic presentation of pronunciation problems and lost some of the feeling of helplessness that a conglomeration of student mispronunciations produces in the instructor. Their students showed a greater interest in English when they saw the mastery of English pronunciation as a series of attainable goals.

In the preparation of these visual aids the following principles were observed:

1. Each card should represent an attainable goal.

2. All vowel phonemes of English should first be dealt with individually, and later in contrast with vowel phonemes that students have difficulty in distinguishing.

3. The presentation of the English vowel system should begin with the familiar, that is, with the vowel phonemes that somewhat resemble the vowel phonemes in the student's own language.

4. The new sound should first be employed in a Spanish word to facilitate the student's hearing and recognizing the sound.

5. English words used for drill purposes should, whereever possible, be:

a. Useful words with phonemically regular spellings. ${ }^{1}$

b. Words with the vowel sound in stressed position.

c. Words with no new and difficult consonant sounds or clusters.

6. To facilitate teaching the prolongation of the English vowel, the order of words in drill lists should, whereever possible, be words with the vowel sound (a) in final position, (b) followed by a voiced consonant, and (c) followed by a voiceless consonant. 2

There are many regular spellings for the sounds of English. The letters $\underline{a}, \underline{e}, \underline{i}, \underline{o}, \underline{u}$, for example, when followed by one or two consonants are generally pronounced $[æ]$, $[\varepsilon],[\mathrm{I}],[\mathrm{a}]$, and $[\partial]$ respectively (bad, rest, list, hot, bus). The letters $\underline{a}, \underline{i}$, $\underline{o}$, when followed by a consonant and a silent $e$ are generally pronounced $[e]$, $[\mathrm{al}]$, and $[0]$ respectively (make, bite, note).

$2_{A}$ voiceless consonant shortens the length of the vowel preceding it. 
7. The phonemic symbol of the sound ${ }^{3}$ with which each card deals should be indicated in small print, solely for teacher reference and guidance.

8. For ready reference different colored cards should be used for each type of problem and numbered in the order of presentation.

9. Cards and print should be sufficiently large to be read easily by every member of the class for which the cards are planned.

10. Spanish words should be printed in small case letters in contrast to English words printed in capital letters.

11. The spelling of the vowel sound in both English and Spanish words, when presented on the same side of the card, should be printed in red; in the lists of words and phrases for dril! purposes, however, only the spolling of the vowel phonemes that do not exist as phonemes in Spanish should be printed in red, in order to call the student's attention to the fact that the spelling represents a phoneme entirely foreign to his language.

The set of visual aids, based on the above principles and entitled Fonemas Ingleses, consists of 29 cards. Each card is 10 by 14 inches in size and is printed on both sides. Three pink cards, for teacher reference only, contain general instructions for the teaching of pronunciation, specific directions for using the cards, reference charts of the English vowel and consonant phonemes, ${ }^{4}$ and a bibliography of useful books dealing with pronunciation. The cards planned for classroom use are divided into three groups.

Group A. Vowels and Diphthongs Similar to Spanish Phonemes

Eight white cards deal with the five English vowel phonemes and the three diphthongs that resemble the five Spanish vowel phonemes and three of the Spanish diphthongs. Students are taught to hear the differences between the English phonemes and theirs, especially the greater length of

${ }^{3}$ See the phonemic analysis in Teaching and Learning English as a Foreign Language Charles C. Fries, University of Michigan Press, 1945.

4 See pages 64 ana 65 
Systematizing the Teaching

of English Vowel Phonemes

the English vowel and of the first part of the English diphthong.

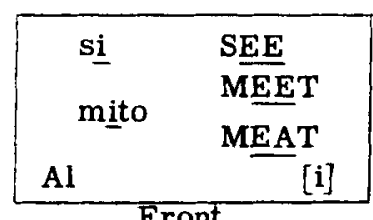

Front

\begin{tabular}{|ll|}
\hline SEA & SEE \\
CLEAN & DEEP \\
READ & SLEEP \\
EAT & WEEK \\
Al & {$[i]$} \\
\hline
\end{tabular}

Back

Note: The underlined letters are printed in red.

In using this group of cards the teacher (1) writes the two Spanish words on the blackboard and calls on a student to read them in Spanish, then pronounces the Spanish word with English sounds, exaggerating the length of the English pronunciation of the Spanish word. (2) The teacher shows the class the front of the card and repeats the English pronunciation of the Spanish word, proceeding directly to the pronunciation of the corresponding English word or words printed in capital letters. The students imitate the teacher's pronunciation. At this stage no effort is made to differentiate the length of the vowel in open syllables from those followed by a voiceless consonant. (3) The words on the back of the card are read by the teacher for student imitation. (4) The same procedure is repeated with the students reading the lists of words.

Group B. Vowel Phonemes not Found in Spanish

Seven blue cards present the English vowel phonemes that do not exist in Spanish. Students are taught to hear and distinguish them from the nearest Spanish phonemes before being taught to. pronounce them:
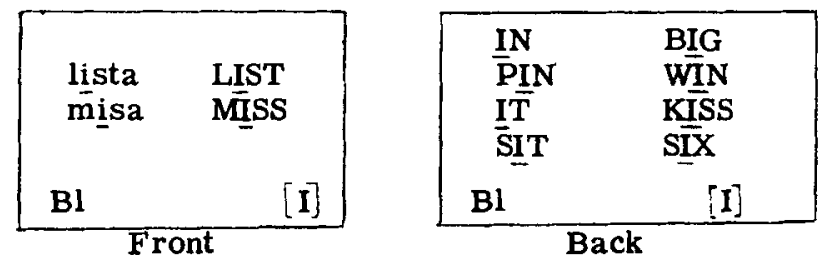
In using this group of cards the teacher (1) writes the two Spanish words on the blackboard and underlines the vowel represented in red. First he pronounces the word in Spanish; then he substitutes the new English sound for the underlined Spanish vowel. Students listen for the difference in sound as the teacher continues pronouncing first the word in Spanish and then the Spanish word with the new English sound. Every time the teacher uses the English sound in the Spanish word, the students show their recognition of this sound by saying, "No," to indicate that this sound is foreign to Spanish. (2) The teacher shows the card and pronounces the Spanish word with an English pronunciation, proceeding directly to the pronunciation of the English words on the right. Students imitate. (3) The students repeat the lists of words on the back of the card, noting carefully that the letters in red represent a phoneme that does not exist in Spanish.

Group C. Vowel Phonemes that students Confuse

Vowel Phonemes that do not exist in Spanish tend to be confused with vowel phonemes that are similar to Spanish phonemes. The purpose of this group of eleven yellow cards is to teach students (a) to hear the difference between pairs of vowel phonemes generally confused by Latin Americans, (b) to pronounce correctly pairs of words in which a difference of meaning results from the use of one or the other of the two vowel phonemes, and (c) to pronounce phrases and short sentences containing the two vowel phonemes generally confused.

\begin{tabular}{|cc|}
\hline 1 & 2 \\
bean & bin \\
bead & bid \\
leave & live \\
beat & bit \\
seat & sit \\
heat & hít \\
[i] & {$[I]$} \\
Cl & \\
\hline
\end{tabular}

Front
1. Eat beans.

2. Sit still.

3. Bill bit his lip.

4. Live in cities.

5. big meals

Cl [i] [I]

Back 


\section{Systematizing the Teaching}

of English Vowel Phonemes

In using this group of cards the teacher (1) reads the first column, exaggerating the length of the vowel; (2) reads the pairs of words across the chart in order to bring out the vowel contrasts; (3) reads one or the other of the pairs of words while the students respond with the number of the column where the word is found, for example: bin...2, bin...2, bean...1, bin...2, bean...1, etc. (4) reads the pairs of words for student imitation, and (5) drills the class on the pronunciation of the phrases and short sentences containing the vowel phonemes. follows:

The content of the drill cards in Fonemas Ingleses

\begin{tabular}{|c|c|c|c|c|c|c|}
\hline$A 1--[i]$ & $\begin{array}{l}\text { si } \\
\text { mito }\end{array}$ & $\begin{array}{l}\text { SEE } \\
\text { MEET } \\
\text { MEAT }\end{array}$ & $\begin{array}{l}\text { SEA } \\
\text { SEE }\end{array}$ & $\begin{array}{l}\text { CLEAN } \\
\text { DEEP }\end{array}$ & $\begin{array}{l}\text { READ } \\
\text { SLEEP }\end{array}$ & $\begin{array}{l}\text { EAT } \\
\text { WEEK }\end{array}$ \\
\hline A2- & seis & SAY & MAY & DAY & BAY & LAY \\
\hline A3-- $[a]$ & ley & $\begin{array}{l}\text { LAKE } \\
\text { SŌCK } \\
\text { CLOCK }\end{array}$ & $\begin{array}{l}\text { NAME } \\
\text { CAR } \\
\text { NOT }\end{array}$ & $\begin{array}{l}\text { SAME } \\
\text { FAR }\end{array}$ & $\begin{array}{l}\text { MAKE } \\
\text { FARM } \\
\text { TOP }\end{array}$ & $\begin{array}{l}\text { LATE } \\
\text { PARK }\end{array}$ \\
\hline A4-- $[\mathbf{u}]$ & tüna & $\begin{array}{l}\text { TOO } \\
\text { MOON }\end{array}$ & $\begin{array}{l}\text { NOT } \\
\text { TOO } \\
\text { BLUE }\end{array}$ & $\begin{array}{l}\text { NOON } \\
\text { TRUE }\end{array}$ & $\begin{array}{l}\text { SOON } \\
\text { MOON }\end{array}$ & $\begin{array}{l}\text { BOX } \\
\text { ROOM } \\
\text { FOOL }\end{array}$ \\
\hline A5-- & bou & $\begin{array}{l}\text { BONEE } \\
\text { BOAT }\end{array}$ & $\begin{array}{l}\text { HOME } \\
\text { SOAP }\end{array}$ & $\begin{array}{l}\text { HOPE } \\
\text { COAT }\end{array}$ & $\begin{array}{l}\text { NOTE } \\
\text { GOAT }\end{array}$ & $\begin{array}{l}\text { DON'T } \\
\text { LOW }\end{array}$ \\
\hline A6-- [ & paila & PIE & MY & TRY & DIE & LE \\
\hline$A 7--[a v]$ & $\begin{array}{l}\text { laico } \\
\text { aúto }\end{array}$ & $\begin{array}{l}\text { LIKE } \\
\underline{\text { OU. TT }}\end{array}$ & $\begin{array}{l}\text { MINE } \\
\text { NOW }\end{array}$ & $\begin{array}{l}\text { NINE } \\
\text { COW }\end{array}$ & $\begin{array}{l}\text { TIME } \\
\text { HOW }\end{array}$ & $\begin{array}{l}\text { LIKE } \\
\text { DOWN }\end{array}$ \\
\hline A 8- & $\begin{array}{l}\text { nauta } \\
\text { estoy } \\
\text { oiga }\end{array}$ & $\begin{array}{l}\text { NOW } \\
\text { TOY } \\
\text { OIL }\end{array}$ & $\begin{array}{l}\text { LOUD } \\
\text { BOY } \\
\text { COIN }\end{array}$ & $\begin{array}{l}\text { FOUND } \\
\text { TOY } \\
\text { POINT }\end{array}$ & $\begin{array}{l}\text { SOUND } \\
\text { JOY } \\
\text { OIL }\end{array}$ & COUNT \\
\hline & lissta & LIST & IN & PIN & IT & SIT \\
\hline & misa & MIISS & $\overline{B I G}$ & $\vec{W} \underline{N}$ & KIISS & SIX \\
\hline & Ema & E्MMA & PEN & $T \underline{E} N$ & BED & LET \\
\hline & dentro & $\overline{D E N}$ & LEEND & CEENT & DESK & BE $\overline{E T}$ \\
\hline & mango & MANGO & MAN & SAD & ADD & FLAG \\
\hline & gas & GA $\underline{\underline{A}}$ & GAS & MAPP & $\overline{\text { A }} \mathbf{S K}$ & $F L \underline{\underline{A}} \bar{T}$ \\
\hline & clubb & CLUB & MUQD & SUيN & FUNN & CQUT \\
\hline & & BU్S & QP & MUQST & DUST & BŨT \\
\hline & & & & & & \\
\hline
\end{tabular}




\begin{tabular}{|c|c|c|c|c|c|c|}
\hline B5-- $[\bar{a} \bar{r}]$ & verbo & VERB & HER & TERM & WORD & WERE \\
\hline & perl & PEARL & $\mathrm{HURT}$ & BURN & BIRD & GIRL \\
\hline & füm: & F $\overline{\mathrm{ULL}}$ & F $\overline{\mathrm{UL} L}$ & $B \overline{\mathrm{UL}} \mathrm{L}$ & PQLLL & $\overline{P U T}$ \\
\hline & fütbol & FŌOT & FŌOT & BŌOK & CÖOKK & LÖOK \\
\hline & $\begin{array}{l}\text { bolsa } \\
\text { toca }\end{array}$ & $\begin{array}{l}\text { BALLL } \\
\text { T } \bar{A} L K\end{array}$ & $\begin{array}{l}A \bar{L} \bar{L} \\
\bar{L} \mathbf{A W}\end{array}$ & $\begin{array}{l}\text { BALL } \\
\text { SAW }\end{array}$ & $\begin{array}{l}\text { TALLL } \\
\text { TALK }\end{array}$ & $\begin{array}{l}\text { WALL } \\
\text { WALK }\end{array}$ \\
\hline
\end{tabular}

C1-- $[\mathrm{i}]$ 1. bean, bead, leave, beat, seat, heat

[i] 2. bin, bidd, live bit, sit, hit
1. Eat beans.
4. Live in cities.
2. Sit still.
5. big. meals

3. Bill bit his lipp.

C2--[e] 1. pain, main, bait, mate, late, sale

[C] 2. pen, men, bet, met, let, sell

1. make dates $\overline{4}$. sell beds

2. Ed fell. 5. get pains

3. Ted met Ed.

C3--[g] 1. pen, ten, beg, bet, fell, well

[j] 2. pinn, tịn, big, bitt, filll, will
1. big pins
2. will beg
4. fill pens
3. let live
5. get in

C4--[E] 1. men, pen, bẹd, beg, bet, set

[X] 2. man, pan, bad, bag, bat, sat
1. Men bet.
4. last man
2. ten cents
3. Ed said, "Yes".
5. Let Dâd get gạs.

C5-- 万a] 1. hot, cop, top, lost, sock, block

$[\dot{\partial}]$ ] 2 hat, cap, tapp, lasst, sack, bla ck
1. not hat
4. glass tops
2. lost blocks
5. Ann's lost hat
3. black caps

C6-- $e^{-1}$ 1. mad, fan, bag, ran, capp, cat

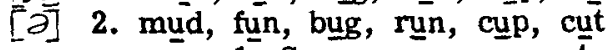
1. Sạm ran.
2. mud huts
4. a rag rug
3. bad luck
5. cut ham 


\section{Systematizing the Teaching of English Vowel Phonemes}

C7--[a] 1. not, hot, cot, cop

2. nut, hut, cut, cup

1. a nut cup

2. a hot cup

3. not $\mathrm{a} \cot$

4. a lot

C8--[ว] 1. bus, dug, cuff, but, lung, sung

[0] 2. bōss, dog, cough, bought, long, song

1. a bus

2. Paul walks.

3. long cuffs

4. bought nuts

C9--[0] 1. boat, coat, sew, coal, cold, woke

[j] 2. bought, caught, saw, call, called, walk

1. Go home.

2. Call Paul.

3. caught cold

4. bought coal

C10-[u] 1. flew, grew, pool, cool

[o] 2. flow, grow, pole, coal

1. cool pool

2. no coal

3. Don't go home.

4. blue coats

C11-[u] 1. pool, fool, moon, noon, soon

2. pull, full, book, took, look

1. blue books

2. full moon

3. look soon

4. füll pool 


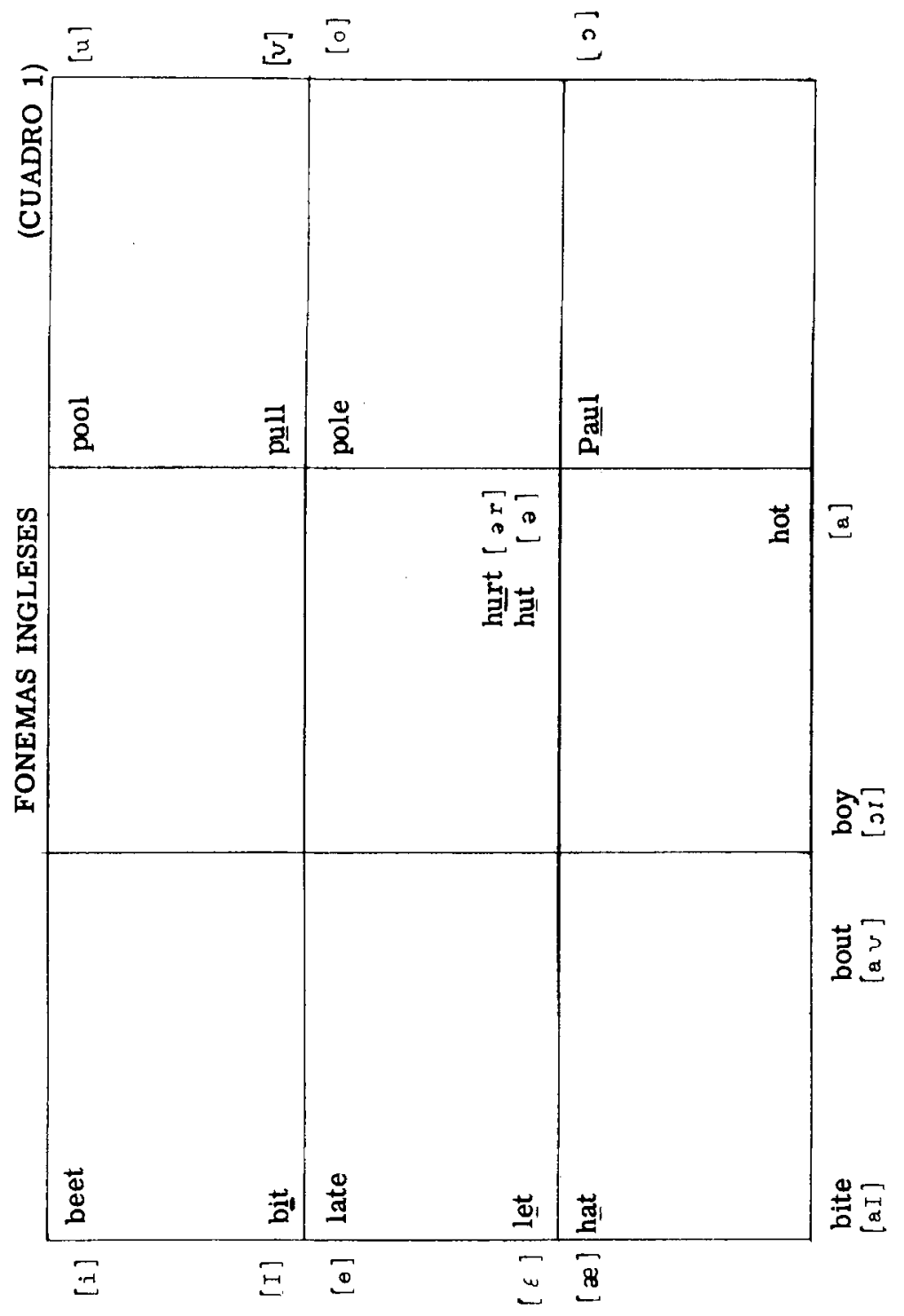




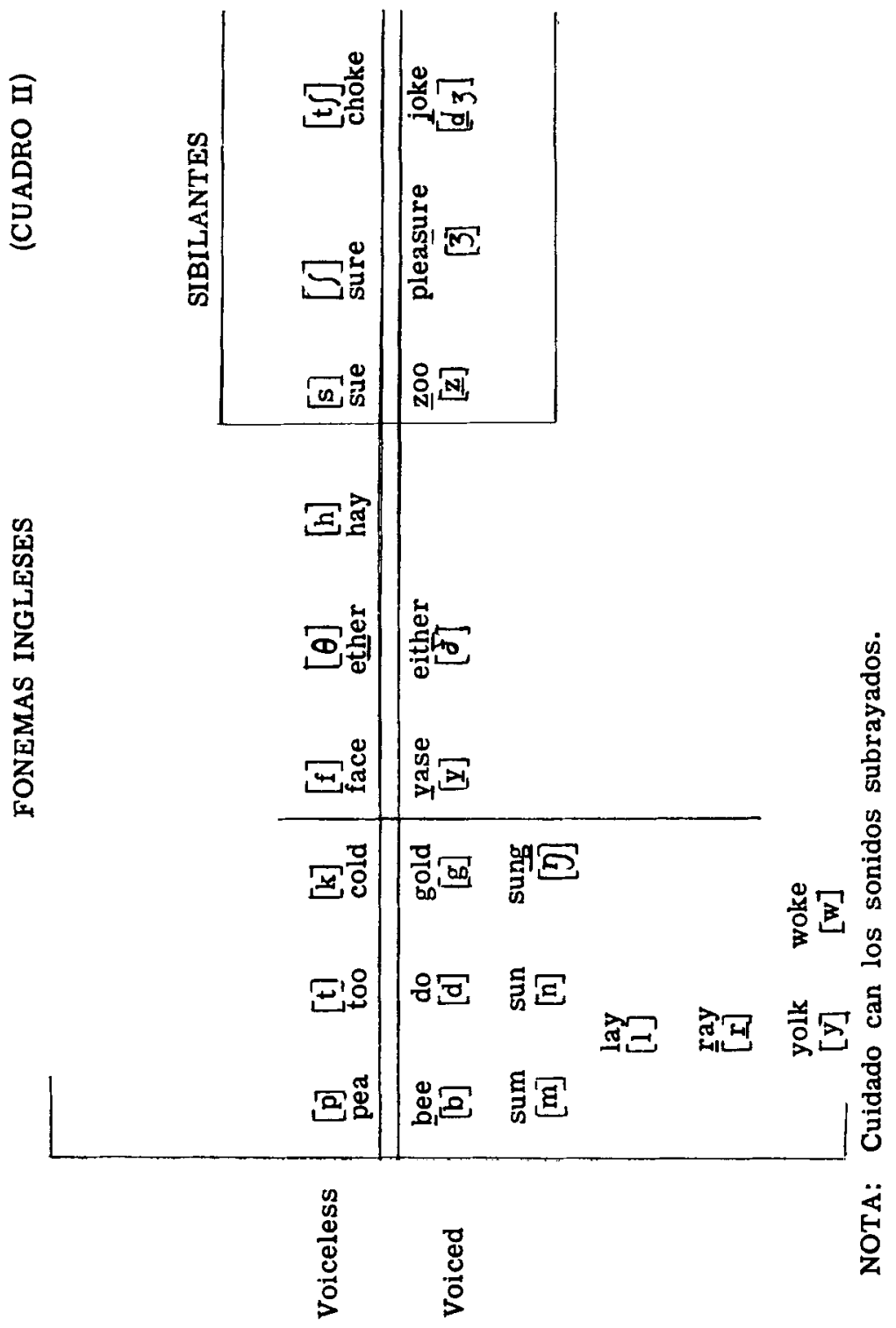

